\title{
Binding of Vitronectin to Opa-Expressing Neisseria gonorrhoeae Mediates Invasion of HeLa Cells
}

\author{
OSCAR G. GÓMEZ-DUARTE, ${ }^{1}$ MICHAELA DEHIO, ${ }^{1}$ CARLOS A. GUZMÁN, ${ }^{2}$ \\ GURSHARAN S. CHHATWAL, ${ }^{2}$ CHRISTOPH DEHIO, ${ }^{1}$ AND THOMAS F. MEYER ${ }^{1,3 *}$ \\ Abteilung Infektionsbiologie, Max-Planck-Institut für Biologie, 72076 Tübingen, ${ }^{1}$ Division of Microbiology, \\ GBF-National Research Centre for Biotechnology, 38124 Braunschweig, ${ }^{2}$ and Abteilung Molekulare Biologie, \\ Max-Planck-Institut für Infektionsbiologie, 10117 Berlin, ${ }^{3}$ Germany
}

Received 21 January 1997/Returned for modification 21 March 1997/Accepted 21 May 1997

\begin{abstract}
Neisseria gonorrhoeae induces local infections in the human genitourinary tract and can disseminate to other organs to cause severe disease. Blood-derived factors present in the genital mucosa have been suggested to facilitate the spread of $N$. gonorrhoeae in disseminated gonococcal infections. Using gentamicin invasion assays and confocal microscopy, we observed a strong stimulatory effect of fetal calf serum (FCS) on the gonococcal invasion of HeLa cells. FCS-mediated invasion was dependent on the expression of the epithelial cell invasionassociated Opa protein (plasmid-encoded Opa $\mathbf{p}_{50}$ or its chromosomal homolog $\mathbf{O p a}_{30}$ ), while $N$. gonorrhoeae expressing noninvasive Opa proteins $\left(\mathrm{Opa}_{51-60}\right)$ or no Opa protein $\left(\mathrm{Opa}^{-}\right)$was not invasive even in the presence of FCS. Incubation of $N$. gonorrhoeae MS11 with biotinylated FCS revealed a 78-kDa protein as the prominent protein binding to $\mathrm{Opa}_{50^{-}}$or $\mathrm{Opa}_{30}$-expressing gonococci. This protein was recognized by antibodies against vitronectin $(\mathrm{VN})$ in Western blots. Purified human or bovine VN efficiently bound to Opa $_{50}$-expressing $^{- \text {exp }}$ gonococci, while binding to noninvasive $\mathrm{Opa}^{-}$or $\mathrm{Opa}_{52}$-expressing gonococci was significantly lower. Binding of VN was inhibited by heparin in a concentration-dependent manner, indicating that the heparin binding sites present in $\mathrm{VN}$ or $\mathrm{Opa}_{50}$ may play an essential role in this interaction. Based on gentamicin invasion assays and confocal microscopy studies, $\mathrm{VN}$ binding was associated with an increased invasion of $\mathrm{Opa}_{50^{-}}$and $\mathrm{Opa}_{30^{-}}$ expressing gonococci into HeLa cells. The ability of $\mathrm{VN}$ to mediate entry into epithelial cells may constitute an important event in the pathogenesis of local as well as disseminated gonococcal infections.
\end{abstract}

Neisseria gonorrhoeae is the causative agent of gonorrhea, a commonly reported sexually transmitted disease in many developing countries and areas in the United States $(7,24,38)$. It affects primarily the genitourinary tract and can spread from the cervix to endometrium, fallopian tubes, and peritoneum, resulting in pelvic inflammatory disease, the most important cause of infertility in women (49). Spread of $N$. gonorrhoeae can also lead to disseminated gonococcal infection (DGI), a disease characterized by skin lesions, polyarthritis, and compromise of internal organs such as the liver, lungs, and heart (17).

$N$. gonorrhoeae infects epithelial cells derived from different organs, e.g., cervix (47), endometrium (46), urethra (1), and ocular conjunctiva (57). Pili facilitate initial adherence to human mucosa in vivo but are not necessary for invasion of epithelial cell lines in vitro (31). Several bacterial factors, including the colony opacity-associated Opa proteins $(26,31$, $57)$, lipopolysaccharide $(40,44,45)$, and the tetrapac locus (15), have been implicated in the invasion process.

Eleven phase-variable Opa proteins, with molecular masses ranging from 24 to $30 \mathrm{kDa}$, have been identified in $N$. gonorrhoeae MS11 (4, 5, 26). Intergonococcal interactions take place by binding of the Opa proteins to the oligosaccharide portion of lipopolysaccharide (6). This interaction correlates with the colony opacity phenotype of Opa protein expression. Opa proteins favor adherence to epithelial cells and have been shown to facilitate phagocytosis by peripheral blood mononuclear cells (26). However, only one Opa protein variant of strain

\footnotetext{
* Corresponding author. Mailing address: Max-Planck-Institut für Biologie, Abteilung Infektionsbiologie, Spemannstr. 34, 72076 Tübingen, Germany. Phone: 497071601 221. Fax: 497071610379. E-mail: sinfbio@mpib-tuebingen.mpg.de.
}

MS11, $\mathrm{Opa}_{30}$ (or its defined invariable recombinant counterpart $\left.\mathrm{Opa}_{50}\right)$, is essential for invasion of Chang cells $(26,31)$ and other cell lines such as Hec1B, HeLa, ME-180, and Int-407 epithelial cells (8). $\mathrm{Opa}_{50^{-}}$or $\mathrm{Opa}_{30}$-expressing gonococci are unable to adhere to or invade epithelial cells in the presence of heparin or enzymes that digest heparan sulfates, indicating that cell surface-associated heparan sulfate proteoglycans serve as receptors for $\mathrm{Opa}_{50^{-}}$or $\mathrm{Opa}_{30}$-expressing gonococci $(9,56)$.

Host extracellular protein factors may bind to $N$. gonorrhoeae and contribute to gonococcal adherence and invasion. These factors may include secreted proteins, protein exudates, and plasma proteins. These components are dramatically increased in female genital mucosa during menstruation, which has been associated with the beginning of DGI in women (20). It is thought that factors present in menstrual blood may contribute to the $N$. gonorrhoeae spread to and invasion of other organs (20). Similarly, detection of gonococci in patients with pelvic inflammatory disease occurs more frequently a few days after menstruation (50). Serum proteins have been implicated in the interaction of $N$. gonorrhoeae (42) and $N$. meningitidis (58) with host cells. Vitronectin (VN), an extracellular matrixassociated protein (51) and a blood component known to bind to multiple integrin receptors (19), promotes adherence of $N$. meningitidis to endothelial cells via the RGD peptide sequence (58). Plasminogen, a component of the fibrinolytic system of plasma, binds to $N$. gonorrhoeae and $N$. meningitidis, although its role in pathogenesis has not yet been determined (54). In vivo studies have also implicated human complement $\mathrm{C} 1 \mathrm{q}$ as a gonococcal protective factor that allows bacteria to infect a nonhuman host (33).

In this study, we describe a factor present in fetal calf serum (FCS) that strongly enhances gonococcal invasion into $\mathrm{HeLa}$ 
cells. This factor has been defined as $\mathrm{VN}$ which binds to $\mathrm{Opa}_{50^{-}}$ or $\mathrm{Opa}_{30}$-expressing gonococci. Consistently, purified VN of both bovine and human origin was found to mediate the uptake of $\mathrm{Opa}_{50^{-}}$or $\mathrm{Opa}_{30^{-}}$-expressing gonococci into HeLa cells. $\mathrm{VN}$-dependent entry of $\mathrm{Opa}_{50^{-}}$or $\mathrm{Opa}_{30^{-}}$-expressing $N$. gonorrhoeae into HeLa cells represents a novel mechanism of gonococcal invasion, the knowledge of which may contribute to a better understanding of the pathogenesis of gonococcal infections.

\section{MATERIALS AND METHODS}

Bacterial strains. $N$. gonorrhoeae strains used in this study were nonpiliated $\left(\mathrm{P}^{-}\right)$derivatives of strain MS11 (26); N392 $\mathrm{Opa}_{30}$ expresses the phase-variable, chromosome-encoded $\mathrm{Opa}_{30}$ protein (31), and N540 Opa ${ }_{50}$ expresses the genetically defined, invariable, plasmid-encoded homolog of $\mathrm{Opa}_{30}$, though at a slightly lower level (23). Both N392 Opa 30 and N540 Opa ${ }_{50}$ represent invasive MS11 derivatives. N540 $\mathrm{Opa}_{50}$ was preferentially used in most of the assays because of its invariable Opa expression. N300 Opa ${ }^{-}$carries a mutation in the $\mathrm{Opa}_{30}$-encoding opaC locus $(23,26)$ and was used as a nonadherent and noninvasive control. N309 $\mathrm{Opa}_{52}$ expresses a defined plasmid-encoded Opa protein known to adhere to, but not invade, human Chang epithelial cells (26) and was used here as an adherent and noninvasive control. Other MS11 derivatives used in this study, which express defined opacity proteins $\left(\mathrm{Opa}_{51-60}\right)$, have also previously been described (26). $N$ gonorrhoeae was grown at $37^{\circ} \mathrm{C}$ with $5 \% \mathrm{CO}_{2}$ on GC phosphate agar (containing, per liter, $3.75 \mathrm{~g}$ of Trypticase peptone [BBL, Becton-Dickinson, Cockeysville, Md.], $7.5 \mathrm{~g}$ of Thiotone E [BBL], $4 \mathrm{~g}$ of $\mathrm{K}_{2} \mathrm{HPO}_{4}, 1 \mathrm{~g}$ of $\mathrm{KH}_{2} \mathrm{PO}_{4}, 5 \mathrm{~g}$ of NaCl, $1 \mathrm{~g}$ of soluble starch [BBL], $1 \%$ Bacto Agar [Difco, Detroit, Mich.] [pH 8.0]) supplemented with 1\% VitaleX (BBL) and antibiotics when appropriate.

Cell culture. HeLa epithelial cells (ATCC CCL2) were originally isolated from a human cervical carcinoma, and Chang epithelial cells (ATCC CCL20.2) were derived from human conjunctiva. Both cell lines were maintained in RPMI 1640 tissue culture medium (Gibco BRL, Gaithersburg, Md.) supplemented with 5\% FCS (HyClone, Logan, Utah) and incubated at $37^{\circ} \mathrm{C}$ and $5 \% \mathrm{CO}_{2}$.

Reagents. Human VN (hVN) was kindly provided by K. T. Preissner. Human fibronectin was obtained from Calbiochem (San Diego, Calif.), and fibrinogen was obtained from Kabi (Uppsala, Sweden). Heparin, laminin, bovine serum albumin (BSA), and bovine VN (bVN) were purchased from Sigma (Deisenhofen, Germany)

Infection experiments. The gentamicin assay was carried out as described before (13), with the following modifications. HeLa cells were seeded in 24-well plates. Confluent monolayers (containing $10^{5}$ cells/well) were infected with $10^{7}$ CFU of bacteria in $1 \mathrm{ml}$ of RPMI 1640 medium without FCS. After addition of $5 \%(\mathrm{vol} / \mathrm{vol}) \mathrm{FCS}, \mathrm{bVN}$, or $\mathrm{hVN}$ at concentrations as indicated or BSA $(1.5$ $\mathrm{mg} / \mathrm{ml}$ ) as a negative control, infected cells were incubated for $6 \mathrm{~h}$ at $37^{\circ} \mathrm{C}$ in $5 \%$ $\mathrm{CO}_{2}$ unless otherwise specified. Wells were then washed three times with phosphate-buffered saline (PBS) to remove unbound bacteria. Infected monolayers were further incubated for $2 \mathrm{~h}$ with fresh RPMI 1640 medium supplemented with $100 \mu \mathrm{g}$ of gentamicin per ml, and then wells were washed three times with PBS before addition of $1 \mathrm{ml}$ of $1 \%$ saponin in PBS for 15 min to lyse epithelial cells. CFU were determined by plating appropriate dilutions from the suspension of lysed cells on GC phosphate agar plates followed by incubation at $37^{\circ} \mathrm{C}$ and $5 \%$ $\mathrm{CO}_{2}$ for $24 \mathrm{~h}$. To determine the number of cell-associated bacteria per well, the assay was performed as described above except that the incubation step with gentamicin was omitted. Samples were tested in duplicate, and experiments were repeated at least twice.

Binding assays with iodinated-labeled proteins. hVN, fibrinogen, fibronectin, and laminin were radiolabeled with ${ }^{125} \mathrm{I}$ (New England Nuclear, Dreieich, Germany) by the chloramine $\mathrm{T}$ method (21) and used to test for binding to $N$. gonorrhoeae strains as described before (25). Assays were done in triplicate.

Binding of gonococci to biotinylated proteins. Detection of proteins binding to gonococci was performed with biotinylated FCS and biotinylated bVN. Biotinylation of proteins was carried out as follows. A 50- $\mu$ l volume of biotin LC (50 $\mu \mathrm{g} / \mathrm{ml}$; Sigma) was added to $2.5 \mu \mathrm{g}$ of bVN (Sigma) or to $1 \mathrm{ml}$ of FCS. The mixture was incubated $1 \mathrm{~h}$ at room temperature, and then a 1:10 volume of $1 \mathrm{M}$ ethanolamine ( $\mathrm{pH} 7.0)$ was added to stop the biotinylation reaction. Binding assays were performed with $10^{8}$ bacteria and $100 \mu \mathrm{l}$ of biotinylated FCS or $1.5 \mu \mathrm{g}$ of biotinylated bVN in a final volume of $1 \mathrm{ml}$ of PBS for $30 \mathrm{~min}$ at $37^{\circ} \mathrm{C}$ with $5 \%$ $\mathrm{CO}_{2}$. To inhibit nonspecific binding, BSA was added to a final concentration of $30 \mathrm{mg} / \mathrm{ml}$. After bacteria were washed three times with PBS to remove unbound biotinylated proteins, the bacterial pellet was lysed in $2 \times$ sodium dodecyl sulfate (SDS) sample buffer and boiled for $5 \mathrm{~min}$ before being loaded onto an SDS-10\% polyacrylamide gel (27). Proteins were electroblotted onto a nitrocellulose membrane, using the semidry Western blotting technique (28). Horseradish peroxidase-streptavidin conjugate in conjunction with an ECL kit (Amersham, Buckinghamshire, England) was used for the developing reaction.

Immunoblot analysis. Binding of FCS or VN to gonococci was evaluated by immunoblotting. Binding assays were carried out as described above, using FCS or purified VN. After bacteria were separated in an SDS-polyacrylamide gel and transferred onto a nitrocellulose membrane, blots were incubated with polyclonal rabbit anti-bVN or monoclonal mouse anti-hVN antibody (both from Calbiochem) overnight at $4^{\circ} \mathrm{C}$. The membrane was subsequently incubated with a goat anti-rabbit or goat anti-mouse immunoglobulin $\mathrm{G}$ (IgG) conjugated to alkaline phosphatase or horseradish peroxidase (all from Sigma). Developing of blots incubated with alkaline phosphatase conjugate was performed with nitroblue tetrazolium-5-bromo-4-chloro-indolylphosphate substrate (Sigma), and blots were incubated with horseradish peroxidase conjugate, using an ECL detection kit (Amersham). Recommendations given by the supplier were followed in either case.

Immunofluorescence labeling and confocal laser scanning microscopy. $\mathrm{HeLa}$ cells were grown and infected as described above except that the cells were seeded onto 12-mm-diameter coverslips placed inside 24-well cell culture plates. Infection was stopped by three washes in PBS, and then the cells were fixed in $3.7 \%$ paraformaldehyde in $200 \mathrm{mM}$ HEPES ( $\mathrm{pH} 7.4$ ) for at least $20 \mathrm{~min}$ at room temperature. Intracellular and adherent extracellular bacteria were differentially stained by indirect immunofluorescence labeling before and after host cell membrane permeabilization. Fixed cells were incubated in BSA $(2 \mathrm{mg} / \mathrm{ml})$ in PBS for $15 \mathrm{~min}$ and then incubated with polyclonal rabbit antigonococcal antiserum AK93 (directed against total gonococci of strain MS11) and Texas red-conjugated goat anti-rabbit IgG antibodies (Dianova, Hamburg, Germany) for $1 \mathrm{~h}$ each. Epithelial cells were then permeabilized in $0.1 \%$ Triton X-100 in PBS, blocked as before, and incubated with AK93 and subsequently with goat antirabbit IgG conjugated to Cy5 (Jackson ImmunoResearch Laboratories, West Grove, Pa.) for $1 \mathrm{~h}$ each. Fluorescein isothiocyanate (FITC)-labeled phalloidin (1 $\mu \mathrm{g} / \mathrm{ml}$; Sigma) was added to the last antibody mixture to stain filamentous actin To label hVN bound to cell-associated gonococci, fixed cells were permeabilized in $0.1 \%$ (vol/vol) Triton X-100 in PBS for $10 \mathrm{~min}$, followed by blocking in BSA $(2 \mathrm{mg} / \mathrm{ml})$ in PBS for $15 \mathrm{~min}$. Samples were subsequently incubated with monoclonal mouse anti-hVN (Calbiochem), goat anti-mouse antibodies conjugated to Texas red (Dianova), rabbit antigonococcal antiserum AK93, and Cy5-conjugated goat anti-rabbit antibodies (Jackson ImmunoResearch Laboratories) and mixed with FITC-labeled phalloidin $(1 \mu \mathrm{g} / \mathrm{ml})$ for $1 \mathrm{~h}$ each. In both staining protocols, coverslips were washed three times in PBS following each incubation step. All antibodies used were diluted $1 / 100$ in PBS. Stained specimens were mounted in $0.1 \mathrm{M}$ Tris $(\mathrm{pH} 8.5)-25 \%$ (wt/vol) glycerol-10\% (wt/vol) Moviol and were viewed with a Leica TCS 4D confocal laser scanning microscope (Leica Lasertechnik, Heidelberg, Germany) equipped with an argon-krypton mixed-gas laser. All three channels were recorded sequentially, and the corresponding images were digitally processed with Photoshop 3.0 (Adobe Systems, Mountain View, Calif.)

\section{RESULTS}

FCS mediates invasion of epithelial cells by $N$. gonorrhoeae

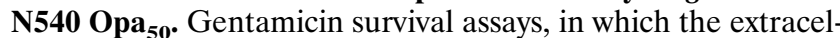
lular bacteria remaining after $6 \mathrm{~h}$ of infection are killed, were carried out to determine the role of FCS in the invasion of epithelial cells by gonococci. Both HeLa and Chang cell lines were tested. HeLa cells are carcinoma cells derived from human endocervix and were originally shown to be invaded by gonococci at relatively low rates (3); Chang cells, derived from human conjunctiva, are regularly used to evaluate gonococcal invasion $(26,31)$. Three derivatives of $N$. gonorrhoeae MS11 were examined: the transparent $\mathrm{N} 300 \mathrm{Opa}^{-}$; N309 $\mathrm{Opa}_{52}$, which expresses the adherent but noninvasive $\mathrm{Opa}_{52}$ protein; and $\mathrm{N} 540 \mathrm{Opa}_{50}$, expressing the invasive Opa 5 protein. HeLa and Chang epithelial cells were infected with each strain and incubated in the presence or absence of 5\% FCS. N300 Opa was unable to invade either HeLa cells or Chang cells in the presence or absence of FCS (Fig. 1). Rates of invasion of HeLa cells by $\mathrm{N} 540 \mathrm{Opa}_{50}$ were dramatically higher in the presence than in the absence of $5 \%$ FCS. Interestingly, invasion of Chang cells by strain N540 Opa ${ }_{50}$ did not depend on FCS and was low compared to invasion of HeLa cells in the presence of FCS. N309 $\mathrm{Opa}_{52}$ did not invade Chang cells even in the presence of FCS but invaded HeLa cells in low numbers independent of FCS. Human serum, previously shown to be bactericidal for gonococci $(14,16,22)$, did not enhance gonococcal invasion of HeLa cells (data not shown). These results indicate that efficient invasion of HeLa cells by N540 Opa ${ }_{50}$ is dependent on FCS, whereas invasion of Chang cells is not, and also that $\mathrm{Opa}_{50}$-mediated invasion of HeLa cells is substantially more efficient than invasion of Chang cells when FCS is added 


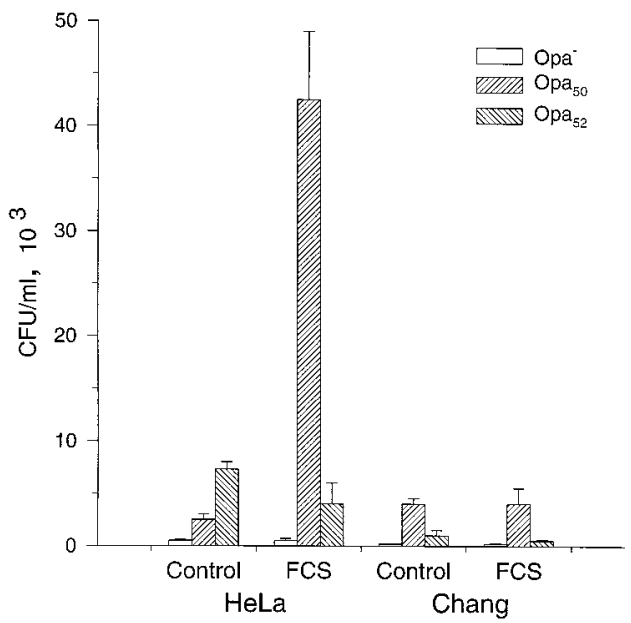

FIG. 1. Gentamicin invasion assay. HeLa cells and Chang cells infected with $\mathrm{N} 300 \mathrm{Opa}^{-}, \mathrm{N} 540 \mathrm{Opa}_{50}$, or N309 $\mathrm{Opa}_{52}$ were incubated in RPMI 1640 medium without (Control) or with (FCS) $5 \%$ FCS for $6 \mathrm{~h}$ at $37^{\circ} \mathrm{C}$. After killing of the extracellular bacteria by gentamicin treatment of infected cells, the number of surviving intracellular bacteria was determined by host cell lysis, plating, and counting of CFU/milliliter. Assays were done in duplicate and repeated at least twice. Error bars represent standard deviations.

to the infected cells. $N$. gonorrhoeae strains expressing recombinant Opa proteins different from $\mathrm{Opa}_{50}$ and $\mathrm{Opa}_{30}$ were unable to efficiently invade HeLa cells either in the absence or in the presence of FCS (data not shown). The influence of FCS on gonococcal invasion was also seen in other human epithelial cell lines, including Hec1B endometrial carcinoma cells, HEp-2 pharynx carcinoma cells, and MCF7 breast adenocarcinoma cells, as well as nonhuman epithelial cell lines such as $\mathrm{COS}$ and $\mathrm{CHO}$, even when a different invasive gonococcal strain, VP1, which expresses a different invasive Opa protein, $\mathrm{Opa}_{27.5}$, was used (31). These data suggest that FCS-mediated invasion of epithelial cells is a general phenomenon not restricted to strain MS11 or HeLa cells.

The effect of FCS on gonococcal invasion of HeLa cells is time and concentration dependent. FCS-dependent invasion of HeLa cells by $\mathrm{N} 540 \mathrm{Opa}_{50}$ and N392 Opa 30 showed the same time dependency as previously reported for FCS-independent invasion of Chang cells (31): invasion took place only in the last $1.5 \mathrm{~h}$ of the standard 6-h invasion assay (data not shown), suggesting that the lag phase of the initial $4.5 \mathrm{~h}$ is required to establish intimate adherence to the host cell. To analyze the time of FCS exposure required for enhancing gonococcal invasion of HeLa cells, infection with $\mathrm{N} 540 \mathrm{Opa}_{50}$ was done for $6 \mathrm{~h}$ in the absence of FCS over the whole period or with $5 \%$ FCS present during the last $30 \mathrm{~min}, 2 \mathrm{~h}$, or the entire 6-h incubation time. Subsequent determination of concentrations (CFU/milliliter) of gentamicin-resistant (intracellular) bacteria indicated that $30 \mathrm{~min}$ of exposure to FCS was sufficient to increase N540 $\mathrm{Opa}_{50}$ entry into HeLa cells. Exposure to FCS for $2 \mathrm{~h}$ resulted in a more substantial increase, reaching approximately $70 \%$ of the invasion levels achieved when FCS was present during the entire 6-h incubation period (Fig. 2A). This result suggests that the establishment of cell adherence in the initial lag phase and triggering invasion by FCS are separate events. Consistently, in a 6-h infection assay, FCS was not found to significantly affect adherence of $\mathrm{N} 540 \mathrm{Opa}_{50}$ to $\mathrm{HeLa}$ cells compared to the absence of FCS, which was independently demonstrated by confocal microscopy (Fig. 3) and by
A

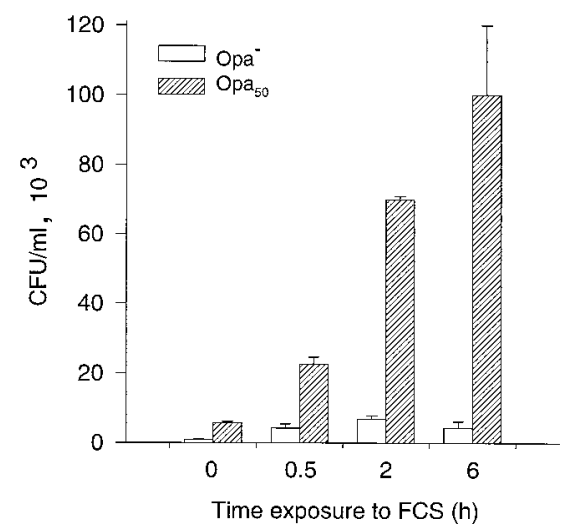

B

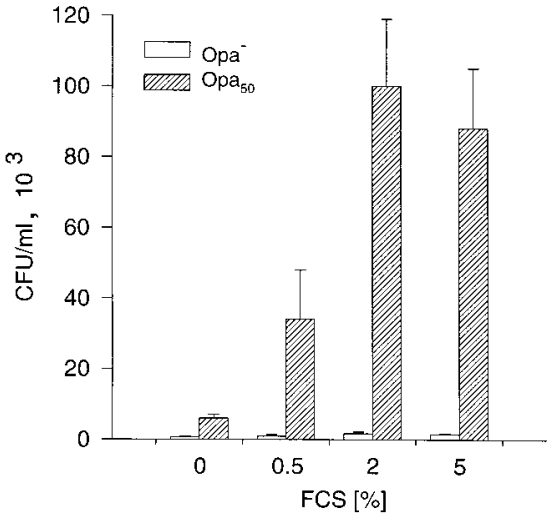

FIG. 2. Time and concentration dependence of gonococcal invasion into HeLa cells on FCS. (A) The effect of time exposure to FCS on gonococcal invasion was examined by infecting HeLa cells with N300 Opa ${ }^{-}$or N540 Opa in RPMI 1640 medium for $6 \mathrm{~h}$ at $37^{\circ} \mathrm{C}$ and $5 \% \mathrm{CO}_{2}$. Infected cells were either not exposed to FCS (0) or exposed to $5 \%$ FCS for the last 0.5 or $2 \mathrm{~h}$ or during the entire 6-h incubation period. To determine the concentration of intracellular bacteria, the infected cell monolayers were further incubated with RPMI 1640 medium containing gentamicin for $2 \mathrm{~h}$ before host cell lysis and plating of bacteria on GC agar. (B) The effect of the concentration of FCS on gonococcal invasion was examined by infecting HeLa cells with $\mathrm{N} 300 \mathrm{Opa}^{-}$or N540 Opa in RPMI 1640 medium containing different FCS concentrations (volume/volume). After $6 \mathrm{~h}$ of infection at $37^{\circ} \mathrm{C}$ and $5 \% \mathrm{CO}_{2}$, the concentration of intracellular bacteria per well was determined as before. All assays were done in duplicate and repeated at least twice. Bars indicate standard deviations.

plating and counting of the cell-associated bacteria (data not shown).

To determine the concentration of FCS necessary to trigger gonococcal invasion, HeLa cells were infected with N540 $\mathrm{Opa}_{50}$ for $6 \mathrm{~h}$ in the absence of FCS or in the presence of 0.5 , 2 or $5 \% \mathrm{FCS}$, and $\mathrm{CFU}$ of intracellular bacteria were determined as described above (Fig. 2B). A significant increase in invasion was observed with $0.5 \%$ FCS present in the assay, while a plateau of maximal invasion rates was reached at $2 \%$ and higher concentrations of FCS.

Identification of proteins from FCS specifically binding to

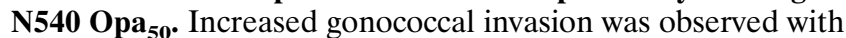
native FCS or FCS heated to $56^{\circ} \mathrm{C}$ for $20 \mathrm{~min}$, while boiling of FCS abolished the invasion-promoting activity (data not shown). This finding suggests that the invasion-inducing factor in FCS may be of a protein nature but also makes an involvement of the complement system unlikely. To identify protein factors present in FCS that bind to Opa-expressing gonococci 


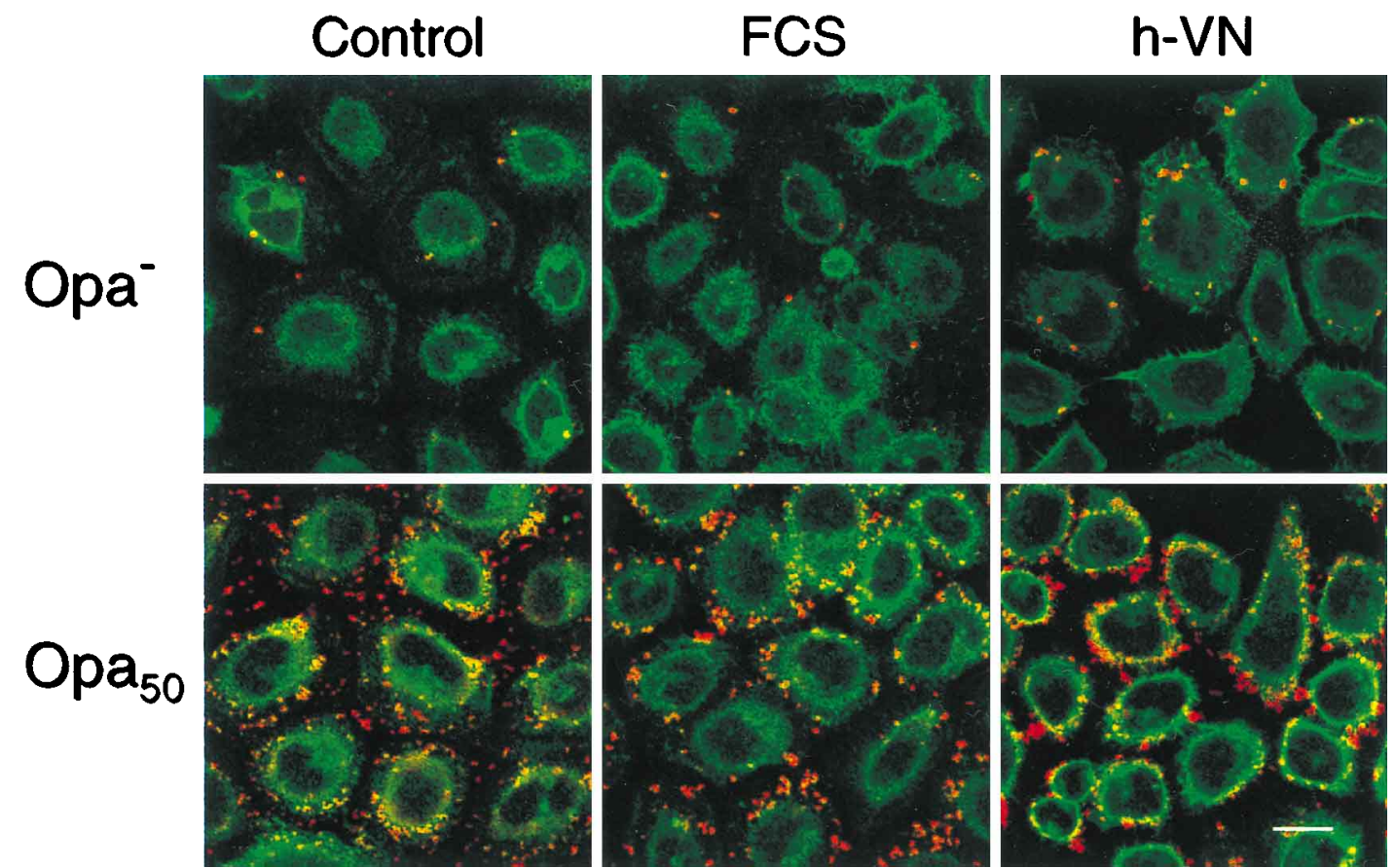

FIG. 3. Confocal analysis of gonococcal adherence to infected HeLa cells. HeLa cells infected with strain $\mathrm{N} 300 \mathrm{Opa}^{-}$or $\mathrm{N} 540 \mathrm{Opa}_{50}$ were incubated for $6 \mathrm{~h}$ at $37^{\circ} \mathrm{C}$ in RPMI 1640 in the presence of 5\% FCS (FCS), $1.5 \mu \mathrm{g}$ of hVN (h-VN), or neither of these reagents (Control). After fixation in paraformaldehyde, infected cells were stained by indirect immunofluorescence labeling of bacteria with rabbit antiserum directed against whole gonococci (AK93) and secondary Texas red-conjugated goat anti-rabbit antibodies (shown in red) before host cell membrane permeabilization and staining of F-actin with FITC-labeled phalloidin (shown in green). The two labels were superimposed to allow the localization of bacteria in relation to cellular structures. The scale bar represents $20 \mu \mathrm{m}$.

and may be implicated in invasion of epithelial cells, gonococci were incubated with biotinylated FCS. After washing of the bacteria, bacterium-bound serum factors were identified by Western blotting of gonococcal lysates, and blots were incubated with streptavidin-conjugated horseradish peroxidase and developed by chemoluminescence (Fig. 4A). Two prominent protein bands of 78 and $65 \mathrm{kDa}$ were observed in the lane representing $\mathrm{N} 540 \mathrm{Opa}_{50}$ incubated with biotinylated FCS, while only one band of $65 \mathrm{kDa}$ was observed in lanes containing N300 $\mathrm{Opa}^{-}$and N309 $\mathrm{Opa}_{52}$. As the latter band is also present in the lane representing N540 Opa 50 which had not been treated with FCS, this band probably represents a biotinylated gonococcal protein.

However, since the bands of 78 and $65 \mathrm{kDa}$ are consistent with the typically double-band electrophoretic mobility of VN (51), the same blotted membrane was incubated with an antibVN antiserum and secondary alkaline phosphatase-conjugated antibodies and developed by using a color reaction. The same bands observed with the streptavidin ECL detection system for biotinylated proteins were detected with the anti-bVN antibody in the N540 $\mathrm{Opa}_{50}$ lane (Fig. 4B). These proteins were not observed in lanes representing N309 Opa 52 or N300 $\mathrm{Opa}^{-}$incubated with biotinylated FCS, implying that the band of $65 \mathrm{kDa}$ observed in Fig. 4A is a different protein comigrating with the low-molecular-weight VN band. Two new bands of 61 and $44 \mathrm{kDa}$ are observed in all lanes containing gonococcal lysates, including the N540 $\mathrm{Opa}_{50}$ lysate without FCS. These proteins were not observed in the lane containing only bVN, indicating that the rabbit anti-bVN antiserum cross-reacts with gonococcal proteins. Expression of Opa protein was tested by immunoblotting, as shown in Fig. 4C. No Opa protein was expressed in $\mathrm{N} 300 \mathrm{Opa}^{-}$, whereas Opa proteins of 30 and 32
$\mathrm{kDa}$ were produced in N540 $\mathrm{Opa}_{50}$ and N309 $\mathrm{Opa}_{52}$, respectively.

The data indicate that $\mathrm{bVN}$ is the major protein present in FCS that binds to N540 $\mathrm{Opa}_{50}$. Lack of binding of bVN to N300 Opa ${ }^{-}$or $\mathrm{N} 309 \mathrm{Opa}_{52}$ suggests that Opa ${ }_{50}$ protein may directly interact with bVN. The nature of the $65-\mathrm{kDa}$ FCS protein binding to $\mathrm{Opa}^{-}$and $\mathrm{Opa}_{50^{-}}$and $\mathrm{Opa}_{52}$-expressing gonococci and its role, if any, in gonococcal infection are unknown.

Binding of VN to $\mathbf{N 5 4 0} \mathbf{O p a}_{\mathbf{5 0}}$. To gain additional evidence for the binding of bVN to gonococci expressing $\mathrm{Opa}_{50}$, immunoblot analysis of gonococci incubated with FCS or purified bVN was performed with rabbit antiserum directed against bVN. As indicated in Fig. 5A, the two typical bVN bands of 78 and $65 \mathrm{kDa}$, present in the bVN control lane, were also observed in the lanes containing the lysate of N540 Opa 50 incubated with FCS or bVN. No corresponding bands were seen in the lane containing N300 Opa ${ }^{-}$incubated with FCS or the lane containing N540 Opa ${ }_{50}$ incubated in the absence of FCS. Binding of $\mathrm{N} 300 \mathrm{Opa}^{-}$to the $78-\mathrm{kDa}$ version of purified bVN was observed, although to a lower degree in comparison with N540 $\mathrm{Opa}_{50}$. The $61-\mathrm{kDa}$ gonococcal protein recognized by the rabbit anti-bVN antiserum and presented in Fig. 4B is also observed in Fig. 5A. Binding of bVN to N540 Opa ${ }_{50}$ is observed after $10 \mathrm{~min}$ of incubation and reaches maximum levels of binding within the first $20 \mathrm{~min}$ (Fig. 5B). To determine if gonococci bind to hVN similarly as to bVN, gonococci were assayed as before, using native hVN. As shown in Fig. 5C, binding of hVN was observed predominantly to N392 Opa and N540 $\mathrm{Opa}_{50}$. Only minor amounts of the $65-\mathrm{kDa}$ version of $\mathrm{hVN}$ were observed to bind to N300 $\mathrm{Opa}^{-}$and to N309 $\mathrm{Opa}_{52}$. No bands were detected in the lane containing lysates of N540 $\mathrm{Opa}_{50}$ without $\mathrm{hVN}$, indicating that the anti-hVN monoclonal 


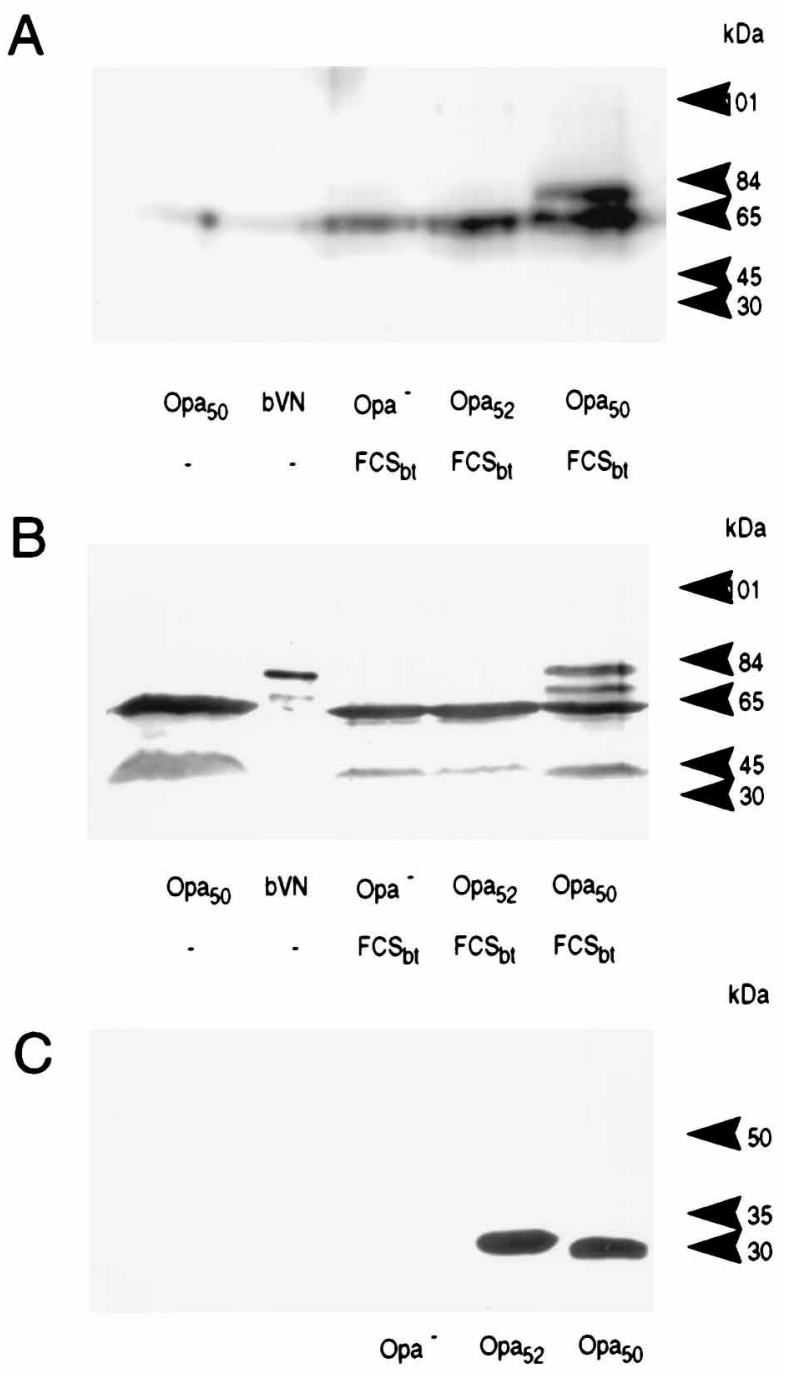

FIG. 4. Identification of vitronectin as a major protein from serum binding to N540 Opa 50 . (A) Western analysis of gonococci incubated with biotin-labeled FCS. Blotted proteins were developed with streptavidin-conjugated horseradish peroxidase and subsequent use of an ECL kit. (B) The blot shown in panel A was incubated with polyclonal anti-bVN antiserum and secondary alkaline phosphatase-conjugated antibodies and developed with a colored alkaline phosphatase substrate. (C) Immunoblot analysis of gonococcal lysates incubated with an anti-Opa antiserum and secondary horseradish peroxidase-conjugated antibodies developed with an ECL kit. Opa ${ }_{50}$, strain N540 Opa ${ }_{50} \mathrm{Opa}^{-}$, strain N300 Opa $\mathrm{Opa}_{52}$, strain N309 $\mathrm{Opa}_{52} ; \mathrm{FCS}_{\mathrm{bt}}$, biotinylated FCS. Arrowheads represent molecular mass markers.

antibody used in Fig. 5C does not cross-react with gonococcal proteins. These results indicate that both bovine and human VN bind predominantly to N540 Opa ${ }_{50}$ and N392 Opa ${ }_{30}$. Low binding of purified bovine and human VN to N300 Opa ${ }^{-}$was not observed with bVN present in FCS, suggesting that proteins present in FCS may saturate nonspecific binding sites for $\mathrm{VN}$ on the gonococcal cell surface.

Binding of hVN to N540 $\mathrm{Opa}_{50}$ was also demonstrated by confocal microscopy. HeLa cells infected with strain N540 $\mathrm{Opa}_{50}$ for $6 \mathrm{~h}$ in the presence of $\mathrm{hVN}$ were triple stained by double indirect immunofluorescence labeling of $\mathrm{hVN}$ and gonococci and by labeling of filamentous actin by FITC-phalloidin. Strong labeling of hVN was observed at the site of gonococcal interaction with the host cell (Fig. 6, h-VN), sug-
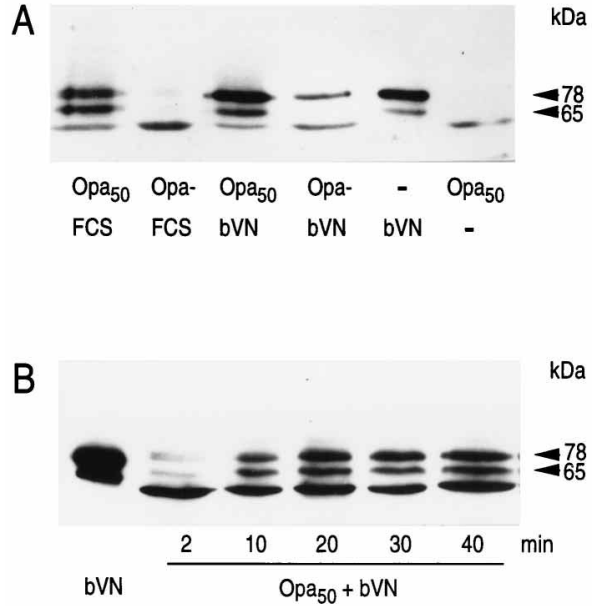

gesting that $\mathrm{hVN}$ has high affinity for $\mathrm{N} 540 \mathrm{Opa}_{50}$. In the absence of hVN from the assay, no labeling of the gonococcal cell surface resulted (Fig. 6, Control), indicating that the monoclonal anti-hVN antibody used did not cross-react with gonococcal proteins. Consistently, this antibody did not show any cross-reactivity with gonococcal proteins on immunoblots (Fig. 5C).

Binding of iodinated hVN to N392 Opa 30 and N540 Opa Further binding experiments using ${ }^{125} \mathrm{I}$-labeled hVN were carried out to confirm the protein analysis data and to better quantify the binding of $\mathrm{hVN}$ to each of the $N$. gonorrhoeae MS11 derivatives. Gonococcal binding to $\mathrm{VN}$ was compared with binding to the integrin-binding proteins fibronectin, laminin, and fibrinogen. ${ }^{125}$ I-labeled VN was incubated with gonococci to determine the degree of binding with respect to Opa expression. As shown in Fig. 7A, both N540 $\mathrm{Opa}_{50}$ and N392 $\mathrm{Opa}_{30}$ were able to bind more than $40 \%$ of the total ${ }^{125} \mathrm{I}$ labeled VN, while N300 $\mathrm{Opa}^{-}$and N309 $\mathrm{Opa}_{52}$ gave lower binding values. Fibronectin and laminin did not bind to gonococci regardless of Opa expression. Binding of fibrinogen to gonococci ranged between 10 and $15 \%$, but no difference was observed with respect to Opa expression.

VN contains a heparin binding site which has been implicated in binding to Staphylococcus aureus, Streptococcus sp., 


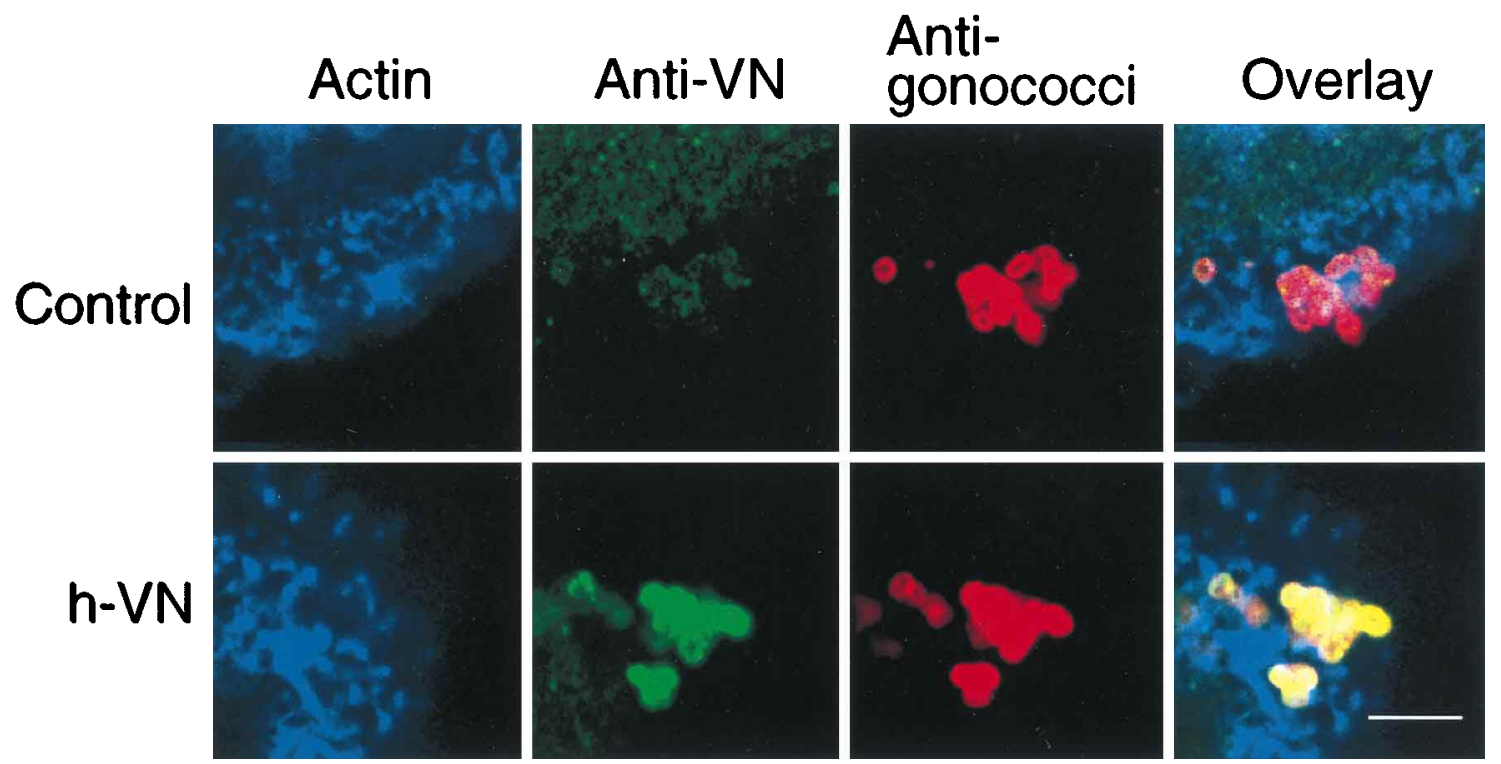

FIG. 6. Demonstration of VN binding to N540 Opa 50 , using indirect immunofluorescence labeling and confocal microscopy. HeLa cells were infected with N540 $\mathrm{Opa}_{50}$ for $6 \mathrm{~h}$ at $37^{\circ} \mathrm{C}$ and $5 \% \mathrm{CO}_{2}$ in RPMI 1640 with $1.5 \mu \mathrm{g}$ of hVN per ml or without hVN (Control). After fixation, infected cells were triple stained by indirect immunofluorescence staining for VN (Anti-VN; green channel) and bacteria (Anti-gonococci; red channel) and staining of filamentous actin by FITC-labeled phalloidin (Actin; blue channel) as outlined in Materials and Methods. Samples were viewed by confocal laser scanning microscopy. The different channels are presented either alone or merged (Overlay). The scale bar represents $5 \mu \mathrm{m}$.

Escherichia coli (10), Helicobacter pylori (43), and Pneumocystis carinii (29). To determine if the heparin binding site of hVN is involved in binding to gonococci, heparin was tested for its ability to compete for binding of $\mathrm{hVN}$ to gonococci. As shown in Fig. 7B, increasing concentrations of heparin were able to compete for binding of ${ }^{125}$ I-labeled hVN to N540 Opa ${ }_{50}$. Heparin concentrations of $50 \mu \mathrm{g} /$ reaction decrease $\mathrm{hVN}$ binding to the background level observed with $\mathrm{N} 300 \mathrm{Opa}^{-}$(data not shown). The background level of hVN binding to N300 Opa was less significantly affected by increasing concentrations of heparin. This result suggests that the binding of hVN to N540 $\mathrm{Opa}_{50}$ may involve the heparin binding site of hVN. Alternatively, binding of heparin to the $\mathrm{Opa}_{50}$ protein itself (56) may interfere with binding of hVN to N540 Opa

Nonlabeled laminin, fibrinogen, or fibronectin was unable to compete with iodinated VN for binding to N540 Opa $\mathrm{O}_{50}$ or N392 $\mathrm{Opa}_{30}$, in contrast with unlabeled hVN, which inhibited binding of iodinated hVN in a concentration-dependent manner (unpublished results), indicating that binding of hVN to $\mathrm{N} 540 \mathrm{Opa}_{50}$ and N392 $\mathrm{Opa}_{30}$ is specific.

VN mediates gonococcal invasion of HeLa cells. As bVN is the main protein in FCS that binds to $\mathrm{Opa}_{30^{-}}$and $\mathrm{Opa}_{50^{-}}$ expressing gonococci, this interaction may contribute to FCSmediated invasion of HeLa cells. Therefore, we performed gentamicin assays to investigate the role of bVN and $\mathrm{hVN}$ in gonococcal invasion of HeLa cells. HeLa cells were incubated with N540 Opa ${ }_{50}$ and N300 Opa ${ }^{-}$in the presence of 5\% FCS or $2 \mu \mathrm{g}$ of native bVN and hVN, respectively, per ml. As shown in Fig. 8A, the invasion of $\mathrm{N} 540 \mathrm{Opa}_{50}$ was $\sim 10$-fold higher in the presence of hVN than in the BSA control, while no effect on invasion was observed with $\mathrm{N} 300 \mathrm{Opa}^{-}$, indicating that $\mathrm{Opa}_{50}$ expression is essential for induction of $\mathrm{VN}$-mediated invasion. bVN stimulated invasion to a similar extent as $\mathrm{hVN}$ (data not shown). FCS increased invasion of strain N540 Opa to higher levels than $\mathrm{VN}$ alone, suggesting either that purified $\mathrm{VN}$ is not as effective as serum $\mathrm{VN}$ in promoting bacterial entry or that factors other than VN may be involved in the FCS-mediated invasion of gonococci.

As previously found for FCS, hVN did not significantly alter the number of cell-associated bacteria compared to the BSA control, as indicated by plating of cell-associated bacteria (data not shown) or by confocal laser scanning microscopy (Fig. 2). However, the adherence pattern of N540 $\mathrm{Opa}_{50}$ (and similarly of $\mathrm{N} 392 \mathrm{Opa}_{30}$ [data not shown]) was different in the presence of $\mathrm{hVN}$ in that clusters of bacteria were found to adhere to the cell surface, while less clustering with FCS and essentially no clustering with BSA were observed. VN-mediated clustering of gonococci might result from bridging by simultaneous interaction of VN with different gonococci. The significance of this phenomenon for the invasion process is not known.

Confocal microscopy was also used to independently assess the role of VN for the invasion of HeLa cells (Fig. 9). Intraand extracellular bacteria were differentially stained by indirect immunofluorescence labeling before and after permeabilization of the host cell membrane. Although the numbers of intracellular bacteria detected by this method varied substantially from cell to cell, the presence of $\mathrm{VN}$ in a regular invasion assay with $\mathrm{N} 392 \mathrm{Opa}_{30}$ allowed the detection of intracellular gonococci in a range of numbers similar to that observed in the presence of FCS, while intracellular bacteria were rarely seen in the absence of VN or FCS (Fig. 9).

hVN exists in two conformations, monomeric (native) and polymeric (denatured). Polymeric hVN has been reported to expose epitopes, normally hidden in native hVN (48), which allows homotypic interactions to occur resulting in the formation of polymeric molecules. To test whether monomeric hVN, which was used in the assays described above, and multimeric $\mathrm{hVN}$ have different effects on stimulating gonococcal invasion of HeLa cells, both protein forms were evaluated at different concentrations in a gentamicin invasion assay. Although native and polymeric hVN increased gonococcal invasion of HeLa cells in similar manners (Fig. 8B), maximum levels of invasion 

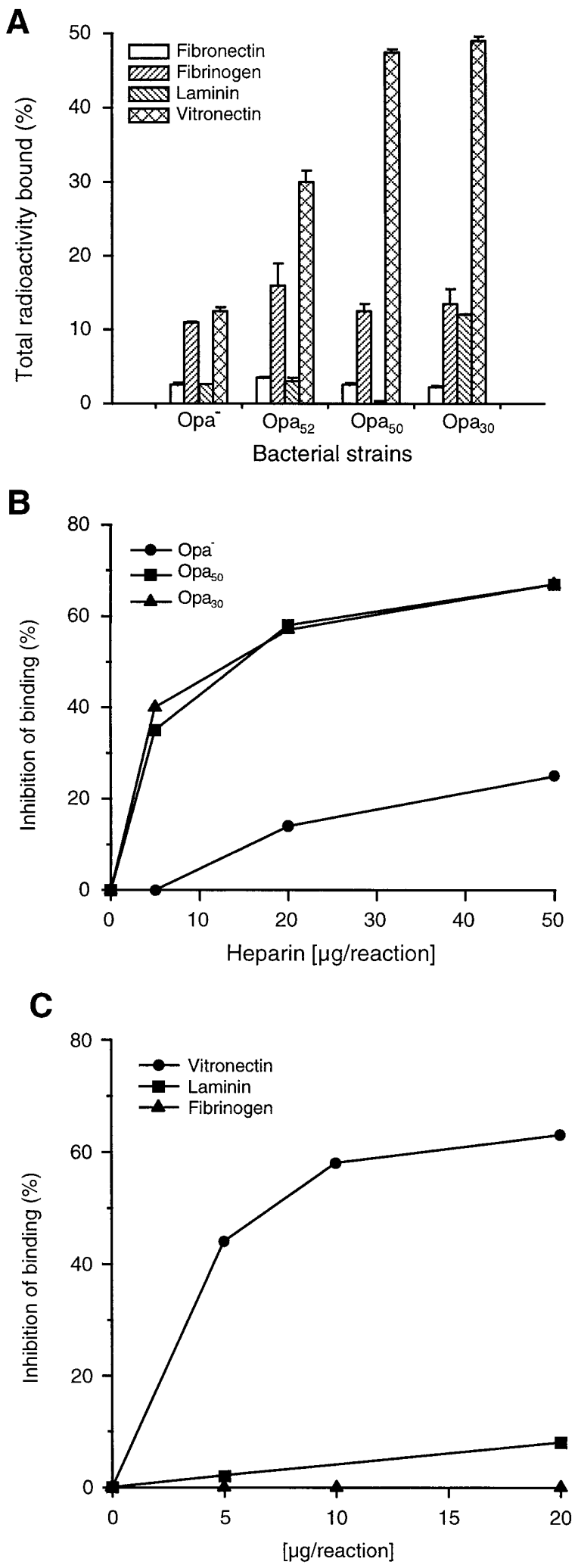

FIG. 7. Binding assays using iodinated proteins. (A) Binding of ${ }^{125} \mathrm{I}$-labeled serum proteins to $\mathrm{N} 540 \mathrm{Opa}_{50}$. Fibrinogen, fibronectin, laminin, and hVN were labeled with ${ }^{125} \mathrm{I}$ as described in the text. The percentage of binding of ${ }^{125} \mathrm{I}$ labeled serum proteins corresponds to the percentage of the total radioactivity present in the assay. The bars represent the means and standard deviations of experiments performed in triplicate. (B) Competition for binding of ${ }^{125} \mathrm{I}-\mathrm{hVN}$ to were reached with $4 \mu \mathrm{g}$ of native hVN per ml, while similar levels were reached with $10 \mu \mathrm{g}$ of multimeric $\mathrm{hVN}$ per ml. Addition of fibronectin at increasing concentrations did not affect invasion of N540 $\mathrm{Opa}_{50}$ (data not shown).

\section{DISCUSSION}

Infection of human mucosal tissues by $N$. gonorrhoeae takes place in the presence of many extracellular factors generally found on the mucus layer or in the extracellular matrix, at the apical or basolateral sides of the epithelial mucosa, respectively. Most of the mucosal factors are either plasma protein exudates or extracellular matrix proteins secreted by the mucosal epithelial cells. Some of these factors are loosely attached to the mucosal surface, as in the case of mucins. Other factors, however, such as extracellular matrix proteins, are tightly bound to epithelial cell plasma membranes. The interplay between host and bacterial factors may determine the outcome of an infection. Host factors, including free extracellular and cellassociated factors, may either impede the gonococcal infection or allow infection to proceed. Although much attention has been placed on the interaction between gonococci and cellassociated factors $(9,56)$, extracellular host factors are the first components encountered by gonococci upon initial contact with the host mucosa. Some extracellular host protein factors, such as lactoferrin, lysozyme, secretory IgA, and complement, prevent the invading microorganism from colonizing $(37,52)$, while other extracellular factors may be used by microbial pathogens to promote infection or spread inside the host. A possible role of plasma proteins in the spread of gonococci during DGI has been reported (20), and in vitro studies have also pointed out that some serum proteins induce gonococcal invasion of epithelial cell $(33,42,54)$. Serum is also rich in many of the extracellular matrix proteins, e.g., $\mathrm{VN}$, laminin, or fibronectin, and therefore often represents a more convenient source for these components than the extracellular matrix itself.

To determine whether factors present in serum can affect invasion of gonococci into HeLa cells, in this study we used FCS, since human serum was previously shown to induce complement-dependent killing of $N$. gonorrhoeae $(14,16,22)$. By using gentamicin invasion assays, to select for intracellular bacteria, and confocal microscopy, we showed that FCS induces gonococcal invasion of HeLa cells whereas gonococcal adherence was not significantly increased. FCS-mediated invasion of HeLa cells depends on the expression of either Opa or $\mathrm{Opa}_{30}$, which is also essential for FCS-independent invasion of Chang cells $(26,31)$. Furthermore, protein analysis indicates that the major protein binding to invasive Opa-expressing gonococci is $\mathrm{VN}$ and that $\mathrm{VN}$ alone is able to mediate gonococcal invasion of HeLa cells. N309 $\mathrm{Opa}_{52}$, known to adhere to epithelial cells (26), is not efficiently internalized in the absence or presence of VN or FCS. This finding suggests that VN does not trigger epithelial cells to indiscriminately engulf adherent bacteria. Instead, VN specifically induces entry of $\mathrm{Opa}_{30^{-}}$or $\mathrm{Opa}_{50}$-expressing gonococci which adhere to HeLa cells.

N540 $\mathrm{Opa}_{50}$ with heparin. The values represent percentages in reduction of binding of ${ }^{125} \mathrm{I}-\mathrm{hVN}$ to gonococci in the presence of increasing concentrations of heparin; $0 \%$ represents the total binding of ${ }^{125} \mathrm{I}$-labeled VN in the absence of heparin. (C) Competition for binding of ${ }^{125}$ I-labeled hVN to N540 Opa 50 with distinct serum proteins. The graph shows the percentage of reduction of ${ }^{125} \mathrm{I}$ hVN to gonococci dependent on the concentrations of nonlabeled serum proteins, i.e., VN, laminin, and fibrinogen. 
A

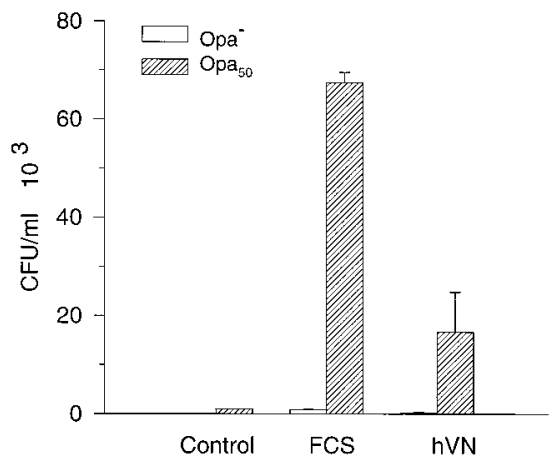

B

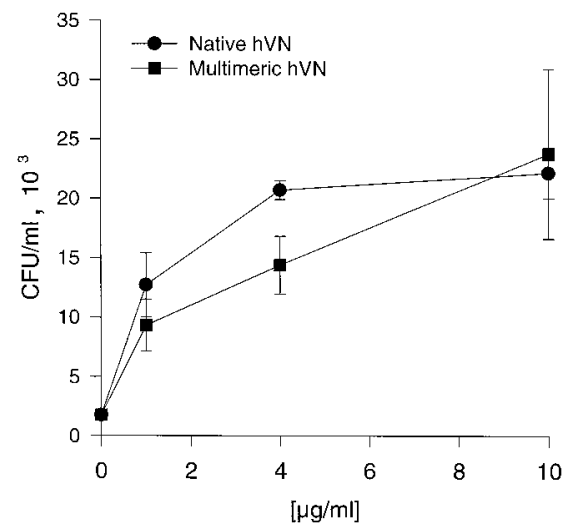

FIG. 8. Effect of VN on gonococcal invasion of HeLa cells. HeLa cells infected with gonococcal strains were incubated with or without human native or human multimeric VN for $6 \mathrm{~h}$, followed by three washes in PBS and $2 \mathrm{~h}$ of treatment with RPMI 1640 supplemented with $100 \mu \mathrm{g}$ of gentamicin per ml. To determine the concentration of intracellular bacteria, the infected cell monolayers were further incubated with RPMI 1640 containing gentamicin for $2 \mathrm{~h}$ before host cell lysis and plating of bacteria on GC agar. (A) Gentamicin assay using 2 $\mu \mathrm{g}$ of native hVN per ml. Gonococcal strains tested included N300 Opa ${ }^{-}$and N540 Opa $\mathrm{Op}_{50}$ (B) Gentamicin assay using N540 Opa 50 and increasing concentrations of native or multimeric hVN. The assay was done in duplicate and repeated three times. The values represent the means of duplicate experiments; bars represent standard deviations.
With respect to how VN may mediate gonococcal invasion, it is pertinent that $\mathrm{VN}$ is an adhesive glycoprotein abundantly present in blood and the extracellular matrix of various tissues and the mucosa (51). It promotes the coagulation cascade by activating and binding plasminogen activator inhibitor 1 (12, 41) and removes inactivated thrombin from circulation by binding to the thrombin-antithrombin complex (11). VN inhibits complement lysis by binding to the soluble membrane attack complex (complement C5b-9), thus protecting bystander cells $(32,39)$. As an extracellular matrix protein, VN promotes cell adhesion $(18,55)$ and cell migration $(30)$, important for cell development, tissue differentiation, and tissue repair after injury. We observed that purified hVN derived from human serum triggered invasion of gonococci into HeLa cells, while whole human serum did not mediate invasion, as it kills gonococci by complement activation $(14,16,22)$. Therefore, the VN pool present in the extracellular matrix of various tissues or mucosas (51) appears to be physiologically more relevant for triggering cell invasion by gonococci, as the bacteriocidal components from serum are basically excluded from these locations.

The multiple role of $\mathrm{VN}$ in bacterial pathogenesis has recently begun to be recognized. VN was shown to bind to $N$. meningitidis (58), S. aureus, streptococci, E. coli (10), and $H$. pylori (43). More importantly, VN was reported to mediate bacterial adhesion to endothelial and epithelial cells $(29,58)$. Interestingly, we found that $\mathrm{VN}$ induces gonococcal internalization in human as well as nonhuman cell lines. This finding, together with the reported interaction of $\mathrm{VN}$ with the abovementioned pathogens, suggests that $\mathrm{VN}$-mediated gonococcal invasion is not a host-specific determinant, even though humans are the only natural hosts for gonococci. The specificity for the human host mostly lies in factors other than VN, including the pilus receptor, transferrin, lactoferrin, and IgA1, the substrate of $\operatorname{IgA} 1$ protease.

$\mathrm{VN}$ is known to interact with integrin receptors of a variety of cells through an RGD sequence and may thereby induce receptor-mediated endocytosis (34-36). The mechanism by which VN mediates gonococcal entry into HeLa cells is not known. One hypothesis is that interaction of the VN gonococcal complex with integrins results in both gonococcal adherence to and activation of receptor-mediated endocytosis in HeLa cells, thereby stimulating bacterial entry. Although VN
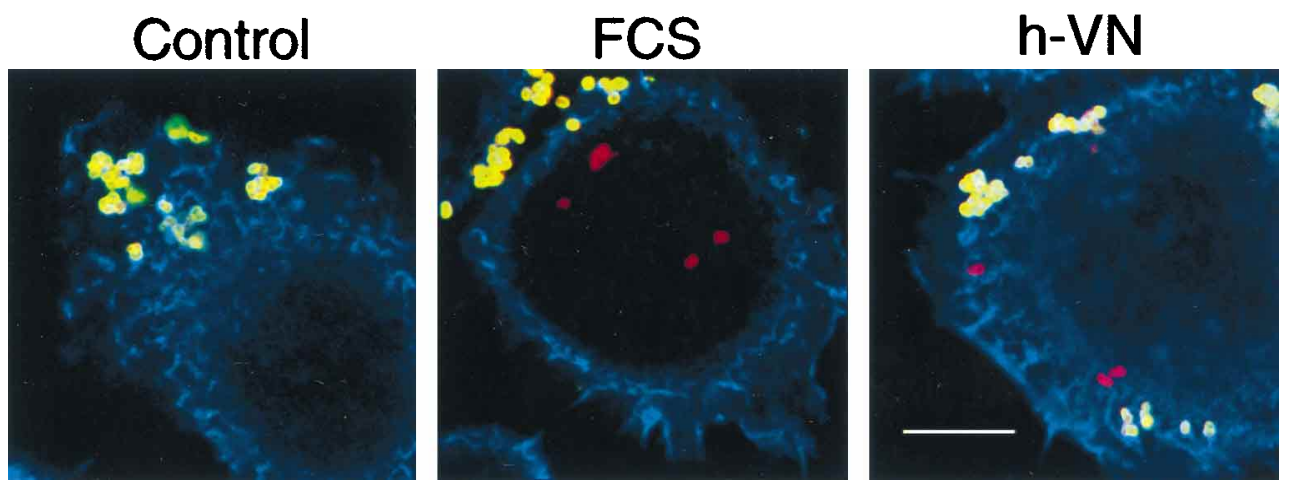

FIG. 9. Confocal analysis of gonococcal invasion into HeLa cells. HeLa cells infected with N300 Opa ${ }^{-}$or N392 Opa 30 were incubated for $6 \mathrm{~h}$ at $37^{\circ} \mathrm{C}$ in RPMI 1640 in the presence of $5 \%$ FCS (FCS) or $1.5 \mu \mathrm{g}$ of human VN (h-VN) or in the absence of these reagents (Control). Bacteria were stained by indirect immunofluorescence labeling before and after host cell membrane permeabilization using Texas red-conjugated (green channel) and Cy5-conjugated (red channel), respectively, secondary antibodies. Cellular F-actin was stained by FITC-labeled phalloidin (blue channel). Specimens were then analyzed by confocal microscopy, and the pictures of all three channels were merged. In this merged picture, intracellular bacteria (pure red, due to signal in the red but not the green channel) can be differentiated from extracellular bacteria (yellow, due to signals in both red and green channels), and the blue signal of cellular actin allows the localization of adherent and intracellular bacteria in relation to the host cell. The scale bar represents $10 \mu \mathrm{m}$ 
has been demonstrated to mediate adherence of $N$. meningitidis to human umbilical endothelial cells (58), VN did not significantly increase gonococcal adherence to HeLa cells. Alternatively, gonococci may adhere to HeLa cells by binding of $\mathrm{Opa}_{30}$ or Opa ${ }_{50}$ to cell surface-associated heparan sulfate proteoglycans (HSPGs), as shown before for VN-independent invasion of Chang cells (56), while bacterial internalization would be triggered by the interaction of the gonococcus-bound VN with its cellular receptors. In this scenario, the mechanism of $\mathrm{VN}$-mediated invasion may be related to the activation of a signal transduction process triggered by the $\mathrm{VN}$-induced crosslinking of HSPGs and the integrin receptors. HSPGs have reportedly been implicated in receptor-mediated endocytosis of VN by integrin receptors via signaling through protein kinase $C$ (36). Protein kinase $C$ is also involved in focal contact formation during cell adhesion to the extracellular matrix. In focal contact formation, integrin-binding proteins such as fibronectin interact with both integrin and HSPGs, which leads to an activation of protein kinase $\mathrm{C}(59,60)$. The tetrafactorial interaction between $N$. gonorrhoeae, VN, HSPGs, and integrin receptors may also engage appropriate signal transduction proteins in the host cell. Studies are under way to define the interactions between VN, gonococci, integrin, and HSPGs which are necessary for gonococcal invasion of epithelial cells and also to characterize the signal transduction mechanisms which will, subsequent to these binding events, trigger bacterial entry into epithelial cells.

\section{ACKNOWLEDGMENTS}

We thank Diana Gómez for technical assistance and Elke Freissler for helpful technical suggestions, Christa Lanz for help with confocal microscopy, Carmen Müller for photography, and K. T. Preissner for the gift of purified $\mathrm{VN}$ and valuable advice.

\section{REFERENCES}

1. Apicella, M. A., M. Ketterer, F. K. N. Lee, D. Zhou, P. A. Rice, and M. S. Blake. 1996. The pathogenesis of gonococcal urethritis in men: confocal and immunoelectron microscopy analysis of urethral exudates from men infected with Neisseria gonorrhoeae. J. Infect. Dis. 173:636-646.

2. Arko, R. J., C. Y. Chen, W. O. Schalla, S. K. Sarafian, C. L. Taylor, J. S. Knapp, and S. A. Morse. 1991. Binding of S protein by Neisseria gonorrhoeae and potential role in invasion. J. Clin. Microbiol. 29:70-75.

3. Bessen, D., and E. C. Gotschlich. 1986. Interactions of gonococci with $\mathrm{HeLa}$ cells: attachment, detachment, replication, penetration, and the role of protein II. Infect. Immun. 54:154-161.

4. Bhat, K. S., C. P. Gibbs, O. Barrera, S. G. Morrison, F. Jahnig, A. Stern, E. M. Kupsch, T. F. Meyer, and J. Swanson. 1991. The opacity proteins of Neisseria gonorrhoeae strain MS11 are encoded by a family of 11 complete genes. Mol. Microbiol. 5:1889-1901.

5. Bihlmaier, A., U. Romling, T. F. Meyer, B. Tummler, and C. P. Gibbs. 1991. Physical and genetic map of the Neisseria gonorrhoeae strain MS11-N198 chromosome. Mol. Microbiol. 5:2529-2539.

6. Blake, M. S., C. M. Blake, M. A. Apicella, and R. E. Mandrell. 1995 Gonococcal opacity: lectin-like interactions between Opa proteins and lipooligosaccharide. Infect. Immun. 63:1434-1439.

7. Centers for Disease Control. 1993. Surveillance for gonorrhea and primary and secondary syphilis among adolescents, United States 1981-1991. Morbid. Mortal. Weekly Rep. 42:55-63.

8. Chen, T., and R. J. Belland. 1994. Adherence and internalization of Opa expressing $N$. gonorrhoeae MS11 by cultured cell lines, p. 621-626. In C. J. Conde-Glez, S. Morse, P. Rice, F. Sparling, and E. Calderon (ed.), Pathobiology and immunobiology of Neisseriaceae. Instituto Nacional de Salud Pública, Cuernavaca, Mexico.

9. Chen, T., R. J. Belland, J. Wilson, and J. Swanson. 1995. Adherence of pilus - Opa + gonococci to epithelial cells in vitro involves heparan sulfate. J. Exp. Med. 182:511-517.

10. Chhatwal, G. S., K. T. Preissner, G. Muller-Berghaus, and H. Blobel. 1987. Specific binding of the human S protein (vitronectin) to streptococci, Staphylococcus aureus, and Escherichia coli. Infect. Immun. 55:1878-1883.

11. de Boer, H. C., K. T. Preissner, B. N. Bouma, and P. G. de Groot. 1995. Internalization of vitronectin-thrombin-antithrombin complex by endothelial cells leads to deposition of the complex into the subendothelial matrix. J. Biol. Chem. 270:30733-30740.
12. Declerck, P. J, M. De Mol, M. C. Alessi, S. Baudner, E. P. Paques, K. T. Preissner, G. Muller-Berghaus, and D. Collen. 1988. Purification and characterization of a plasminogen activator inhibitor 1 binding protein from human plasma. Identification as a multimeric form of $\mathrm{S}$ protein (vitronectin). J. Biol. Chem. 263:15454-15461.

13. Elsinghorst, E. A. 1994. Measurement of invasion by gentamicin resistance. Methods Enzymol. 236:405-420.

14. Frank, M. M., K. Joiner, and C. Hammer. 1987. The function of antibody and complement in the lysis of bacteria. Rev. Infect. Dis. 9(Suppl. 5):537545.

15. Fussenegger, M., A. F. Kahrs, D. Facius, and T. F. Meyer. 1996. Tetrapac (tcp), a novel genotype of Neisseria gonorrhoeae affecting epithelial cell invasion, natural transformation competence and cell separation. Mol. Microbiol. 19:1357-1372.

16. Griffiss, J. M., G. A. Jarvis, J. P. O'Brien, M. M. Eads, and H. Schneider 1991. Lysis of Neisseria gonorrhoeae initiated by binding of normal human IgM to a hexosamine-containing lipooligosaccharide epitope(s) is augmented by strain-specific, properdin-binding-dependent alternative complement pathway activation. J. Immunol. 147:298-305.

17. Handsfield, H. H. 1975. Disseminated gonococcal infection. Clin. Obstet. Gynecol. 18:131-142.

18. Hayman, E. G., M. D. Pierschbacher, S. Suzuki, and E. Ruoslahti. 1985 Vitronectin-a major cell attachment-promoting protein in fetal bovine serum. Exp. Cell Res. 161:245-258.

19. Hess, S., S. M. Kanse, C. Kost, and K. T. Preissner. 1995. The versatility of adhesion receptor ligands in haemostasis: morpho-regulatory functions of vitronectin. Thromb. Haemostasis 74:258-265. (Review.)

20. Holmes, K. K., G. W. Counts, and H. N. Beaty. 1971. Disseminated gonococcal infection. Ann. Intern. Med. 74:979-993.

21. Hunter, W. H., and F. C. Greenwood. 1962. Preparation of iodine-131 labelled human growth hormone of high specific activity. Nature 194:495-496.

22. Jarvis, G. A. 1994. Analysis of C3 deposition and degradation on Neisseria meningitidis and Neisseria gonorrhoeae. Infect. Immun. 62:1755-1761.

23. Kahrs, A. F., A. Bihlmaier, D. Facius, and T. F. Meyer. 1994. Generalized transposon shuttle mutagenesis in Neisseria gonorrhoeae: a method for isolating epithelial cell invasion-defective mutants. Mol. Microbiol. 12:819-831.

24. Kohl, P. K. 1994. Epidemiology of sexually transmitted diseases. What does it tell us? Sex. Transm. Dis. 21:S81-S83.

25. Kronvall, G., E. B. Myhre, L. Björck, and I. Berggård. 1978. Binding of aggregated human $\beta_{2}$-microglobulin to surface protein structure in group $A$ $\mathrm{C}$, and $\mathrm{G}$ streptococci. Infect. Immun. 22:136-142.

26. Kupsch, E. M., B. Knepper, T. Kuroki, I. Heuer, and T. F. Meyer. 1993 Variable opacity (Opa) outer membrane proteins account for the cell tropisms displayed by Neisseria gonorrhoeae for human leukocytes and epithelial cells. EMBO J. 12:641-650.

27. Laemmli, U. K. 1970 . Cleavage of structural proteins during the assembly of the head of bacteriophage T4. Nature 227:680-685.

28. Lauriere, M. 1993. A semidry electroblotting system efficiently transfers both high- and low-molecular-weight proteins separated by SDS-PAGE. Anal. Biochem. 212:206-211.

29. Limper, A. H., J. E. Standing, O. A. Hoffman, M. Castro, and L. W. Neese. 1993. Vitronectin binds to Pneumocystis carinii and mediates organism attachment to cultured lung epithelial cells. Infect. Immun. 61:4302-4309.

30. Lydon, M. J., and C. A. Foulger. 1988. Cell-substratum interactions: serum spreading factor. Biomaterials 9:525-527.

31. Makino, S., J. P. van Putten, and T. F. Meyer. 1991. Phase variation of the opacity outer membrane protein controls invasion by Neisseria gonorrhoeae into human epithelial cells. EMBO J. 10:1307-1315.

32. Milis, L., C. A. Morris, M. C. Sheehan, J. A. Charlesworth, and B. A. Pussell. 1993. Vitronectin-mediated inhibition of complement: evidence for different binding sites for C5b-7 and C9. Clin. Exp. Immunol. 92:114-119.

33. Nowicki, S., M. G. Martens, and B. J. Nowicki. 1995. Gonococcal infection in a nonhuman host is determined by human complement C1q. Infect. Immun. 63:4790-4794.

34. Panetti, T. S., and P. J. McKeown-Longo. 1993. Receptor-mediated endocytosis of vitronectin is regulated by its conformational state. J. Biol. Chem. 268:11988-11993.

35. Panetti, T. S., and P. J. McKeown-Longo. 1993. The alpha v beta 5 integrin receptor regulates receptor-mediated endocytosis of vitronectin. J. Biol. Chem. 268:11492-11495.

36. Panetti, T. S., S. A. Wilcox, C. Horzempa, and P. J. McKeown-Longo. 1995 Alpha v beta 5 integrin receptor-mediated endocytosis of vitronectin is protein kinase C-dependent. J. Biol. Chem. 270:18593-18597.

37. Petersen, B. H., J. A. Graham, and G. F. Brooks. 1976. Human deficiency of the eighth component of complement. The requirement of $\mathrm{C} 8$ for serum Neisseria gonorrhoeae bactericidal activity. J. Clin. Invest. 57:283-290.

38. Piot, P., and M. Q. Islam. 1994. Sexually transmitted diseases in the 1990s. Global epidemiology and challenges for control. Sex. Transm. Dis. 21:S7S13.

39. Podack, E. R., and H. J. Muller-Eberhard. 1979. Isolation of human Sprotein, an inhibitor of the membrane attack complex of complement. J. Biol. Chem. 254:9908-9914. 
40. Porat, N., M. A. Apicella, and M. S. Blake. 1995. A lipooligosaccharidebinding site on HepG2 cells similar to the gonococcal opacity-associated surface protein Opa. Infect. Immun. 63:2164-2172.

41. Preissner, K. T., J. Grulich-Henn, H. J. Ehrlich, P. Declerck, C. Justus, D. Collen, H. Pannekoek, and G. Muller-Berghaus. 1990. Structural requirements for the extracellular interaction of plasminogen activator inhibitor 1 with endothelial cell matrix-associated vitronectin. J. Biol. Chem. 265:1849018498 .

42. Richardson, W. P., and J. C. Sadoff. 1988. Induced engulfment of Neisseria gonorrhoeae by tissue culture cells. Infect. Immun. 56:2512-2514.

43. Ringner, M., K. H. Valkonen, and T. Wadstrom. 1994. Binding of vitronectin and plasminogen to Helicobacter pylori. FEMS Immunol. Med. Microbiol. 9:29-34

44. Robertson, B. D., M. Frosch, and J. P. van Putten. 1993. The role of galE in the biosynthesis and function of gonococcal lipopolysaccharide. Mol. Microbiol. 8:891-901.

45. Schwan, E. T., B. D. Robertson, H. Brade, and J. P. van Putten. 1995. Gonococcal rfaF mutants express Rd2 chemotype LPS and do not enter epithelial host cells. Mol. Microbiol. 15:267-275.

46. Shaw, J. H., and S. Falkow. 1988. Model for invasion of human tissue culture cells by Neisseria gonorrhoeae. Infect. Immun. 56:1625-1632.

47. Simon, D., and R. F. Rest. 1992. Escherichia coli expressing a Neisseria gonorrhoeae opacity-associated outer membrane protein invade human cervical and endometrial epithelial cell lines. Proc. Natl. Acad. Sci. USA 89: $5512-5516$.

48. Stockmann, A., S. Hess, P. Declerck, R. Timpl, and K. T. Preissner. 1993. Multimeric vitronectin. Identification and characterization of conformationdependent self-association of the adhesive protein. J. Biol. Chem. 268:22874-22882.

49. Sweet, R. L. 1987. Sexually transmitted diseases. Pelvic inflammatory disease and infertility in women. Infect. Dis. Clin. N. Am. 1:199-215.

50. Sweet, R. L., D. L. Draper, and W. K. Hadley. 1981. Etiology of acute salpingitis: influence of episode number and duration of symptoms. Obstet. Gynecol. 58:62-68.

51. Tomasini, B. R., and D. F. Mosher. 1991. Vitronectin. Prog. Hemostasis Thromb. 10:269-305.

52. Tramont, E. C. 1977. Inhibition of adherence of Neisseria gonorrhoeae by human genital secretions. J. Clin. Invest. 59:117-124.

53. Tran Van Nhieu, G., and R. R. Isberg. 1994. Isolation and identification of eukaryotic receptors promoting bacterial internalization. Methods Enzymol. 236:307-318.

54. Ullberg, M., P. Kuusela, B. E. Kristiansen, and G. Kronvall. 1992. Binding of plasminogen to Neisseria meningitidis and Neisseria gonorrhoeae and formation of surface-associated plasmin. J. Infect. Dis. 166:1329-1334.

55. Underwood, P. A., and F. A. Bennett. 1989. A comparison of the biological activities of the cell-adhesive proteins vitronectin and fibronectin. J. Cell Sci. 93:641-649.

56. van Putten, J. P., and S. M. Paul. 1995. Binding of syndecan-like cell surface proteoglycan receptors is required for Neisseria gonorrhoeae entry into human mucosal cells. EMBO J. 14:2144-2154.

57. Virji, M., and J. S. Everson. 1981. Comparative virulence of opacity variants of Neisseria gonorrhoeae strain P9. Infect. Immun. 31:965-970.

58. Virji, M., K. Makepeace, and E. R. Moxon. 1994. Distinct mechanisms of interactions of Opc-expressing meningococci at apical and basolateral surfaces of human endothelial cells; the role of integrins in apical interactions. Mol. Microbiol. 14:173-184.

59. Woods, A., and J. R. Couchman. 1992. Heparan sulfate proteoglycans and signalling in cell adhesion. Adv. Exp. Med. Biol. 313:87-96.

60. Woods, A., and J. R. Couchman. 1992. Protein kinase C involvement in focal adhesion formation. J. Cell Sci. 101:277-290.

Editor: P. E. Orndorff 